\title{
Species Diversity and Tree Regeneration Patterns in Tropical Forests of the Western Ghats, India
}

\author{
R. Jayakumar ${ }^{1}$ and K. K. N. Nair ${ }^{2}$ \\ ${ }^{1}$ Centre for Environmental Management of Degraded Ecosystems, School of Environmental Studies, University of Delhi, \\ Delhi 110007, India \\ ${ }^{2}$ Department of Forest Botany, Kerala Forest Research Institute, Thrissur, Kerala 680653, India
}

Correspondence should be addressed to R. Jayakumar; jayakumar.uday@gmail.com

Received 5 February 2013; Accepted 19 April 2013

Academic Editors: C. Jarnevich and T. Karels

Copyright (c) 2013 R. Jayakumar and K. K. N. Nair. This is an open access article distributed under the Creative Commons Attribution License, which permits unrestricted use, distribution, and reproduction in any medium, provided the original work is properly cited.

Study Aim. To assess species diversity and tree regeneration patterns of different vegetation types of Western Ghats, India. Rarefaction was used to estimate species diversity of different vegetation types. One-way ANOVA was used to test for differences in tree density and basal area of different vegetation types. Sorenson index of similarity was used to calculate change in species composition between mature trees and regenerating individuals. Results showed that species diversity and regeneration pattern of trees differ in different vegetation types of the forest landscape. Species-area and species-individual accumulation curve (rarefaction) against equal-sized sampling area in different vegetation types showed that species heterogeneity was higher in vegetation types at mid elevations while their abundance was higher in vegetation types at higher elevations. All the vegetation types of the study area were heterogeneously distributed. Tree regeneration was higher in species rich vegetation type with no sign of human disturbances. Change in species composition across mature and regenerating phase was more frequent in disturbed forest as compared to undisturbed or less disturbed forests. New entry species occur in all the vegetation types.

\section{Introduction}

Tropical regions of the world are frequently decked with luxuriant vegetation rich in species. The diversity of tree species is a fundamental component of total biodiversity in many ecosystems because trees are ecosystem engineers that provide resources and habitats for almost all other forest organisms [1]. In tropical forests, the diversity of tree species varies by geography, habitat parameters, and levels of disturbance [2]. Trees form the major structural and functional basis of tropical forest ecosystems and can serve as robust indicators of changes and stressors at the landscape scale [3]. The spatial heterogeneity of diversity may be the result of some underlying pattern or process such as environmental heterogeneity, biotic control, and abiotic/biotic coupling process [4]. Spatial patterns of species richness have been used extensively to identify biodiversity "hotspots" [5]. The assumption is that managing areas of high species richness equate to improved conservation outcomes. Therefore richness usually was a positive predictor of places of conservation value, if these are defined as places where species of interest are especially abundant. Understanding species diversity and distribution patterns is important for helping managers to evaluate the complexity and resources of these forests.

Quantitative plant diversity inventories of Indian tropical forests are available from various forests of Western Ghats [28-36]. Comparison of the species diversity of different vegetation types is often difficult because of the dissimilarity of the available data. Primary forests of Asia, especially those of the Western and Eastern Ghats of India, are fast disappearing due to diverse anthropogenic impacts. The primary stands are often replaced by forests of secondary species; alternatively, forest landscapes are converted to completely different uses [37]. Earlier studies of tropical tree regeneration have focused mainly on seedlings, which are usually more abundant than other life stages [38-40]. Parameters of seedling stands are crucial components of tree population dynamics [41]. As floristic and structural composition changes from one 
community to another there are concomitant changes in the competitive abilities of seedlings that depend on shifting opportunities for regeneration [42]. Recruitment, growth, and survival are influenced by a range of microclimatic and edaphic factors, which vary among different tropical forest formations [43]. Phillips [44] analyzed tree turnover in 67 mature forest sites representing most of the major tropical forest regions of the world; across the sites, tree turnover had significantly increased since the 1950s. Increased tree turnover has positive impacts on atmospheric quality and biodiversity [1].

The Indian subcontinent has one of the world's richest floras, with more than 17,000 species of flowering plants alone [45]. The Western Ghats, one of the biodiversity "hotspots," in which our study was performed, form a mountainous region in peninsular India that extends $1400 \mathrm{~km}^{2}$ from the mouth of the Tapti River in the north to the environs of Kanyakumari in the south [46]. With this background, we evaluated the diversity and regeneration patterns of tree species in a section of the Nilgiri Biosphere Reserve, aiming to provide fundamental data for appropriate management strategies (mainly to propose the study area as Protected Area) that will improve the ecosystem. Specifically, we (i) aim to examine and compare tree species diversity (richness, abundance, and basal area) in six different vegetation types representative of the study area (ii) to assess tree distribution pattern (using Raunkiaer's frequency class) and also tree girth distribution of different vegetation of the study area and (iii) to determine natural regeneration patterns and changes in species compositions across mature and regenerating phases of trees and also assess occurrence of new entry species in different representative forest types of the landscape.

\section{Methods}

2.1. Study Area. The study was conducted in the New Amarambalam Reserve Forests (Figure 1), which is situated in the Western Ghats of India $\left(11^{\circ} 14^{\prime}-11^{\circ} 24^{\prime} \mathrm{N}, 76^{\circ} 11^{\prime}-76^{\circ} 33^{\prime} \mathrm{E}\right)$. These stands are part of the Nilgiri Biosphere Reserve within the State of Kerala. The reserve covers an area of about $265 \mathrm{~km}^{2}$. Following the forest type terminology of UNESCO [47], the natural vegetation types of the area were tropical broad-leaved drought deciduous forests (DECI), tropical lowland broad-leaved semideciduous seasonal forests (SEMI), tropical lowland broad-leaved seasonal evergreen forests (EVER), tropical broad-leaved evergreen/submontane forests (SUBM), tropical broad-leaved seasonal evergreen/montane forests (MONT), and tropical broad-leaved drought deciduous woodlands (WOOD). DECI occurred in foothills of Ghats with reduced rainfall, whereas the other forest formations occurred at higher elevations that received rain through most of the year. DECI occurred in an altitudinal range of 40$400 \mathrm{~m}$ above mean sea level. Other vegetation types occurred at elevations of $400-2554 \mathrm{~m}$ (Table 1). In addition to six vegetation types, another forest formation occurs on the top of the Ghats (altitudinal range of 1800-2554 m) called short grass savannah that has practically no tree species, excluded from the present study. Temperature in the study area ranged from 17 to $37^{\circ} \mathrm{C}$; diurnal variation seldom exceeded $16^{\circ} \mathrm{C}$. The area received an average rainfall of about $2600 \mathrm{~mm}$, reaching a maximum of $6000 \mathrm{~mm}$. Most precipitation fell in the SouthWest monsoon season, which extends from June through the end of September. High altitudes in the Ghats had rainfall through most of the year. The monsoon precipitation was highest on western, southwestern, and northwestern slopes. The climate was hot from March to May and humid during the rainy season.

2.2. Disturbances and Threats to the Study Area. Forests near human habitations (DECI) are highly degraded by firewood collection and cattle grazing; this has led to impoverished plant diversity in the area. Seasonal fire in WOOD damages many ecosystem components, including trees and their seedlings. Remaining four vegetation types are more or less undisturbed. Poaching and fishing are also common in the area. Fish are killed with copper sulphate and explosives (locally known as Thotta), with indiscriminate killing of many species of aquatic fauna and flora. In the face of such dangers, the rich, diverse, and dynamic forest formations of the region, which contain rare, endangered, and threatened (RET) tree species [48], require species-, location-, and issuespecific management strategies in addition to the overall protection provided by the Nilgiri Biosphere Reserve.

2.3. Vegetation Sampling and Species Diversity Analysis. In the period 2000-2003, we used a stratified random design to sample vegetation [47]. The trees in the vegetation types were classified into three growth phases: mature trees $(\geq 30 \mathrm{~cm}$ girth at breast height [gbh]), saplings ( $\geq 10<30 \mathrm{~cm}$ gbh), and seedlings ( $<10 \mathrm{~cm}$ gbh and $>20 \mathrm{~cm}$ high). Initially, all standing trees $>10 \mathrm{~cm}$ gbh were counted in $30 \mathrm{~m} \times 30 \mathrm{~m}$ plots (i.e. $900 \mathrm{~m}^{2}$ or 0.09 hectare [ha]) laid randomly in each vegetation type. Within each plot, ten random subplots of $2 \mathrm{~m} \times 2 \mathrm{~m}$ were also deployed; in these, we collected data on tree seedlings. A total of 23 ha contained 259 sampling plots. The number of plots deployed in each vegetation type was 45 ( 4 ha) except for WOOD where total area (34 plots) was sampled. Altitudes of plots were measured with a pocket altimeter accurate to $20 \mathrm{~m}$. Tree gbh values were measured at $1.3 \mathrm{~m}$ above ground level.

To assess species-area and species-individuals (abundance) relationship and also estimate average species accumulation rate of different vegetation types, species-area curves and species-individual rarefaction curves (individualbased rarefaction) were created, randomly selected 30 plots of $30 \mathrm{~m} \times 30 \mathrm{~m}$ size. Rarefaction was used to investigate the richness of the community expected in a random sample of individuals taken from a census or collection. The heterogeneity index, namely, Shannon index was measured using the formula: $H^{\prime}=\sum\left[\left(n_{i} / N\right) \log _{e}\left(n_{i} / N\right)\right]$, where $H^{\prime}$ is Shannon diversity index, $n_{i}$ is number of individuals of species " $i$ " in a community sample, and $N$ is total number of individuals of all species in the community sample [49]. Vegetation data including density (number of individuals $\left.\mathrm{ha}^{-1}\right)$, richness (number of species), and basal area $\left(\mathrm{m}^{2} \mathrm{ha}^{-1}\right)$ were assembled. To assess species distribution, Raunkiaer 


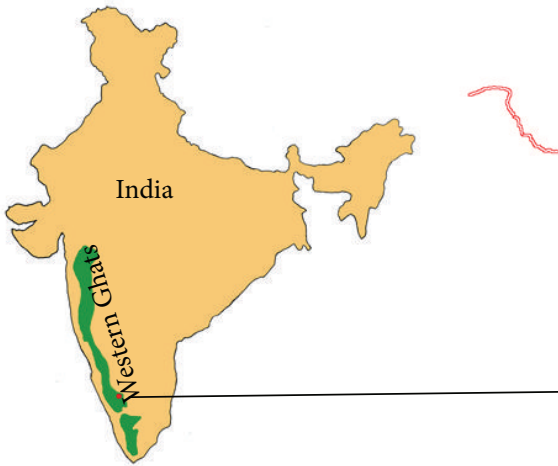

Location of Nilgiri Biosphere Reserve Nilgiri Biosphere Area - State boundary Location of New Amarambalam RF within the Nilgiri Biosphere Reserve

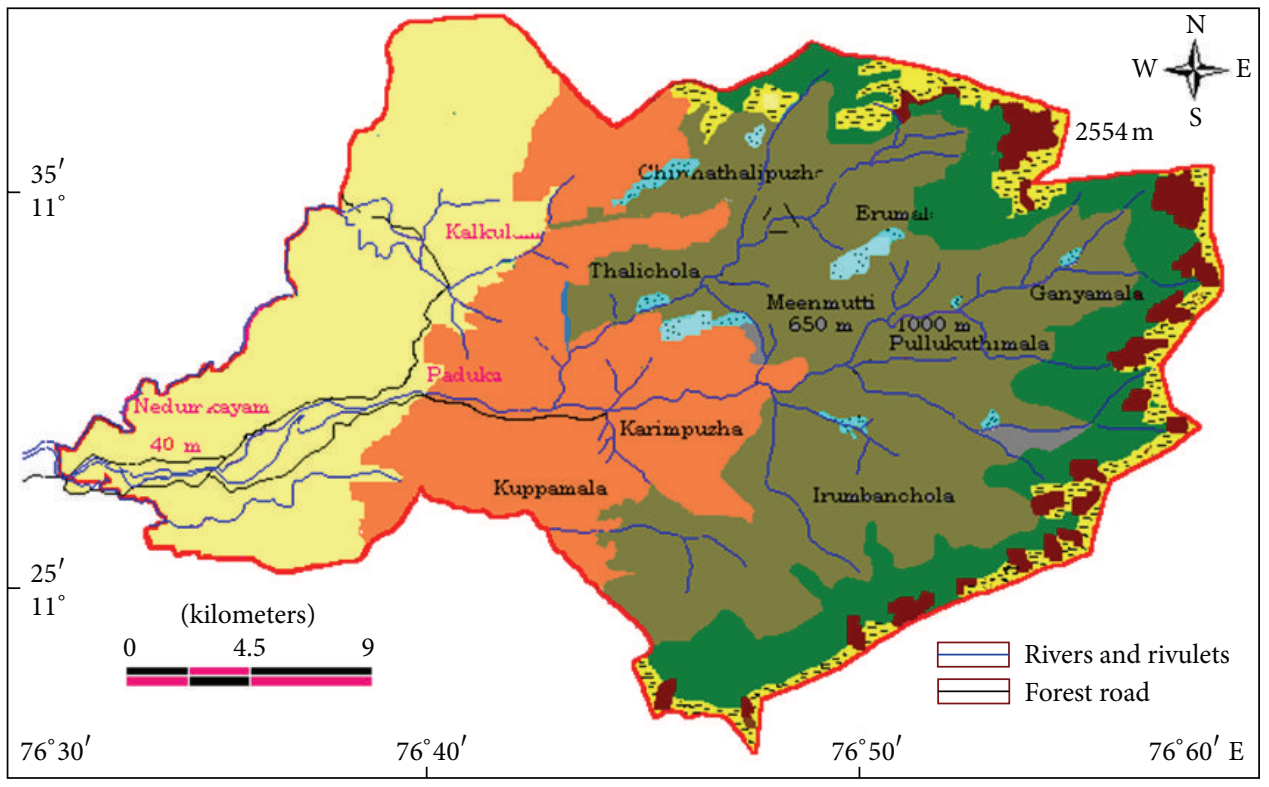

\footnotetext{
$\square$ Tropical broad-leaved drought deciduous forests (DECI)

Tropical lowland semideciduous seasonal forests (SEMI)

Tropical lowland broad-leaved seasonal evergreen forests (EVER)

Tropical broad-leaved submontane forests (SUBM)

::: Tropical broad-leaved drought deciduous woodlands (WOOD)

$\square$ Tropical broad-leaved montane forests (MONT)
}

FIgURE 1: Location and area maps of New Amarambalam Reserve Forests and adjoining forests.

[50] divided percent frequency into five classes: A (0-20\%), B (21-40\%), C (41-60\%), D (61-80\%), and E (81-100\%) to assess distribution of species. Frequency diagrams represent the homogeneity or heterogeneity of a community as floristic uniformity varies with the value for classes $\mathrm{A}$ and $\mathrm{E}$. When classes $\mathrm{A}, \mathrm{B}$, and $\mathrm{C}$ are relatively frequent, the stand is heterogeneous and the greater the frequency of class $\mathrm{E}$, the greater the homogeneity. To assess girth pattern, ghb of trees $(>10 \mathrm{~cm}$ gbh) of all the vegetation types was measured and categorized into different girth class interval of $50 \mathrm{~cm}$.
2.4. Regeneration. The regeneration status of a tree species in a given forest type was considered "good" when seedling density > sapling density > adult tree density, "fair" when seedling density $>$ sapling density $\leq$ adult density, "poor", when the species survived in only the sapling stage but not in the seedling stage, "none", for species with no sapling or seedling stages but present as adult trees, and "new" when adults of a species were absent but sapling and/or seedling stage(s) were present [31]. When a species frequency distribution fits a "reverse J" pattern (high number of individuals in 
TABLE 1: Dominant trees (first three) and their densities (trees ha ${ }^{-1}$ ) in three different growth phases of six vegetation types. International (UNESCO) and regional (Champion and Seth, 1968 ${ }^{*}$ ) terminology of vegetation types used. See "regeneration" in Section 2 for procedure used to distinguish dominant species.

\begin{tabular}{|c|c|c|c|c|c|}
\hline \multicolumn{2}{|c|}{ Vegetation types } & \multirow{2}{*}{ Dominant species } & \multicolumn{3}{|c|}{ Density of tree phases } \\
\hline UNESCO & Champion and Seth (1968) & & Mature & Saplings & Seedlings \\
\hline \multirow{7}{*}{$\begin{array}{l}\text { Tropical broad-leaved } \\
\text { drought deciduous } \\
\text { forests } \\
\text { (DECI) }\end{array}$} & \multirow{7}{*}{$\begin{array}{l}\text { Southern tropical moist } \\
\text { deciduous forests }\end{array}$} & Xylia xylocarpa & 25.9 & 23 & 3166 \\
\hline & & Terminalia paniculata & 22.8 & 5.2 & 333 \\
\hline & & $\begin{array}{l}\text { Lagerstroemia } \\
\text { microcarpa }\end{array}$ & 15.6 & 1.2 & - \\
\hline & & Wrightia tinctoria & 10.8 & 8.6 & 166 \\
\hline & & Holarrhena pubescens & - & 2.5 & 4833 \\
\hline & & Bridelia airy-shawii & 0.3 & 0.2 & 4666 \\
\hline & & Radermachera xylocarpa & 1.3 & 1 & 3500 \\
\hline \multirow{6}{*}{$\begin{array}{l}\text { Tropical lowland } \\
\text { broad-leaved } \\
\text { semideciduous seasonal } \\
\text { forests } \\
\text { (SEMI) }\end{array}$} & \multirow{6}{*}{$\begin{array}{l}\text { West coast tropical } \\
\text { semievergreen forests }\end{array}$} & Pterygota alata & 49 & 81.5 & 245 \\
\hline & & $\begin{array}{l}\text { Reinwardtiodendron } \\
\text { anamalaiense }\end{array}$ & 30 & 85 & 3845 \\
\hline & & Strombosia zeylanica & 16 & 8.5 & 456 \\
\hline & & Palaquium ellipticum & 14 & 9.6 & 240 \\
\hline & & Xylia xylocarpa & 19 & 12 & 96 \\
\hline & & Calophyllum polyanthum & 3.6 & 5.5 & 453 \\
\hline \multirow{5}{*}{$\begin{array}{l}\text { Tropical lowland } \\
\text { broad-leaved seasonal } \\
\text { evergreen forests } \\
\text { (EVER) }\end{array}$} & \multirow{5}{*}{$\begin{array}{l}\text { West coast tropical evergreen } \\
\text { forests }\end{array}$} & Palaquium ellipticum & 93 & 38 & 4136 \\
\hline & & Agrostistachys borneensis & 71 & 69 & 223 \\
\hline & & Myristica beddomei & 39 & 27 & 573 \\
\hline & & $\begin{array}{l}\text { Reinwardtiodendron } \\
\text { anamalaiense }\end{array}$ & 28 & 56 & 1636 \\
\hline & & Calophyllum polyanthum & 4 & 1.5 & 1042 \\
\hline \multirow{6}{*}{$\begin{array}{l}\text { Tropical broad-leaved } \\
\text { drought deciduous } \\
\text { woodlands } \\
\text { (WOOD) }\end{array}$} & \multirow{6}{*}{ Subtropical hill savannahs } & Wendlandia thyrsiflora & 17 & 36 & 356 \\
\hline & & Phyllanthus emblica & 3.2 & - & - \\
\hline & & Glochidion ellipticum & 2.3 & 2.4 & - \\
\hline & & Gnidia glauca & 2.38 & 18 & 160 \\
\hline & & Macaranga peltata & 1.59 & 4 & - \\
\hline & & Erythrina stricta & 0.8 & 1.6 & 80 \\
\hline \multirow{4}{*}{$\begin{array}{l}\text { Tropical broad-leaved } \\
\text { evergreen/submontane } \\
\text { forests (SUBM) }\end{array}$} & \multirow{4}{*}{$\begin{array}{l}\text { Southern subtropical } \\
\text { broad-leaved hill forests }\end{array}$} & Myristica beddomei & 88 & 0.5 & 765 \\
\hline & & Palaquium ellipticum & 55 & 15 & 298 \\
\hline & & Litsea stocksii & 32 & 35 & 456 \\
\hline & & Litsea floribunda & 4 & 5 & 371 \\
\hline \multirow{6}{*}{$\begin{array}{l}\text { Tropical broad-leaved } \\
\text { evergreen/montane } \\
\text { forests } \\
(\mathrm{MONT})\end{array}$} & \multirow{6}{*}{$\begin{array}{l}\text { Southern montane wet } \\
\text { temperate forests }\end{array}$} & Turpinia cochinchinensis & 116 & 46 & 1855 \\
\hline & & Rhododendron arboreum & 102 & 34 & 206 \\
\hline & & Symplocos obtusa & 64 & 33 & 386 \\
\hline & & Rhodomyrtus tomentosa & 26 & 44 & 234 \\
\hline & & $\begin{array}{l}\text { Syzygium } \\
\text { calophyllifolium }\end{array}$ & 77 & 20 & 868 \\
\hline & & Litsea floribunda & 30 & 7 & 870 \\
\hline
\end{tabular}

${ }^{*}$ Champion, H. G. and Seth, S. K. 1968. A revised survey of the forest types of India. Oxford, UK and IBH Publications, New Delhi, India.

the seedling stage and gradually declining numbers through the sapling, small tree, and mature tree phases), that species was recognized as the dominant in the whole stand. In order to measure number of species shared between mature and regenerating phases, Sorenson index of similarity [49] was used: $S=2 c /(a+b)$, where $S$ is Sorenson index of similarity, $c$ is number of species shared between growth phases (here mature tree phase and regenerating phase, i.e. saplings + seedlings), $a$ is total number of species in growth phase $a$, and $b$ is total number of species in growth phase $b$. Species is considered as new recruit when there was no tree species with mature (adult) stage. 


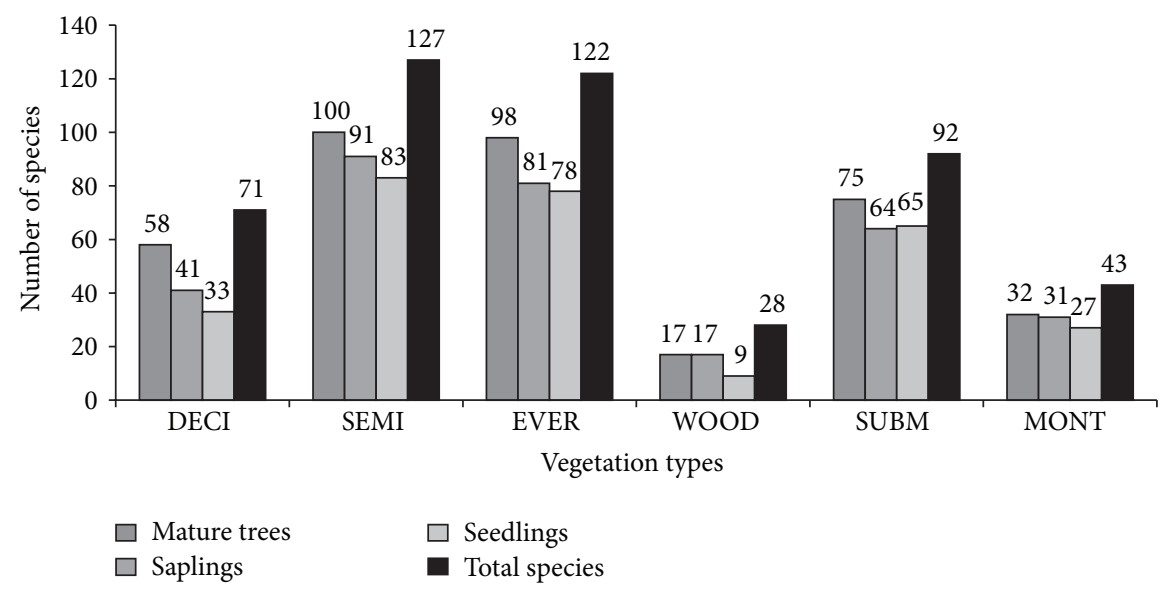

FIGURE 2: Species richness (number of species) by tree growth phase in six vegetation types occurring in the Western Ghats. Multiple comparison LSD post hoc test showed richness of all the vegetation types was significantly different $(P<0.01-0.05)$. See Table 1 for an explanation of vegetation type abbreviations.

2.5. Statistical Analysis. One-way ANOVA was used to test differences of density ( $\geq 30 \mathrm{~cm}$ gbh), overall species richness, and basal area among vegetation types. LSD post hoc tests were used to detect significant pair wise differences among means of dependent variables. One-way analysis of covariance (ANCOVA) was conducted to test of the covariate (abundance) is that it evaluates the relationship between the covariate (abundance) and the dependant variable (species richness), controlling for the factor (vegetation types). Pearson correlation coefficients were calculated to detect significant correlations among vegetation parameters especially cumulative species richness and abundance of each vegetation type. We used the statistical package SPSS (Version 16: www-01.ibm.com/software/analytics/spss/) for all tests. For rarefaction we used statistical software Biodiversity Pro (http://www.smi.ac.uk/peter-lamont/biodiversity-pro).

\section{Results}

3.1. Species Diversity. In the six vegetation types sampled in the study area, there were 257 tree species belonging to 62 families and 147 genera of angiosperms. Richness of tree species (Figure 2) was highest in SEMI (127 spp.) and lowest in the WOOD (28 spp.). Species-area and species-individuals accumulation curve (rarefaction curve) against equal-sized sampling areas in different vegetation types showed a distinct difference in the richness and abundance. Rarefaction can be used to examine the evenness of the distribution of species in assemblages by comparing steepness of curves. Steeper rarefaction curves indicate high heterogeneity. One striking results of rarefaction curves was that SEMI and EVER have the highest curves. This means that species diversity per equal-sized area was highest in these vegetation types but MONT has the most individuals per unit area. Vegetation type at other extreme (low species richness) was WOOD and MONT (Figure 3). The overall difference in species richness among six vegetation types was statistically significant $\left(F_{5,179}=65.1 ; P<0.0001\right)$. Species richness and corresponding abundance were significantly positively correlated in all the vegetation types (DECI: $r=0.98, P<$ 0.0001); SEMI: $r=0.95, P<0.0001$, EVER: $r=0.94, P<$ 0.0001; WOOD: $r=0.77, P<0.0001$; SUBM: $r=0.95, P<$ 0.0001 ; MONT: $r=0.87, P<0.0001)$. A primary analysis evaluating the homogeneity-of-regression (slopes) assumption indicated that the relationship between the covariate (abundance) and the dependant variable (species richness) differs significantly as a function of the independent variable (vegetation types) $\left(R^{2}=0.152 ;\right.$ ANCOVA: $F_{6,179}=133.4$, $P<0.001)$. A significant interaction between the covariate and the factor suggests that the differences on the dependent variable among groups vary as a function of the covariate. Since the result from the ANCOVA was significant, it is not meaningful to proceed further. The highest Shannon index value occurred in SEMI (3.67 for plants with $\mathrm{gbh} \geq 30 \mathrm{~cm}$ ) and lowest value reported in WOOD (Table 2).

Dominant tree species in mature and sapling stages were more or less similar in most vegetation types, but dominant species in the seedling stage varied considerably (Table 1). Overall stand density of mature trees $(\geq 30 \mathrm{~cm}$ gbh) was highest in MONT (855 trees ha ${ }^{-1}$ ) and lowest in WOOD (39 trees ha ${ }^{-1}$ ). Densities of both tree saplings and seedlings were highest in EVER (Figure 4). Among 25 tree species dominant across the different forest types, 16 dominated in the tree phase, 15 in the sapling phase, and 14 in the seedling phase. Among the different forest types, there were significant difference in tree $(\geq 30 \mathrm{~cm}$ gbh $)$ density $\left(P<0.0001, F_{5,389}=\right.$ 26.9) and basal area $\left(P<0.007, F_{5,389}=3.3\right)$. Mean basal area of trees was highest in $\operatorname{EVER}\left(48 \mathrm{~m}^{2} \mathrm{ha}^{-1}\right)$ and lowest in WOOD (Table 2).

Raunkiaer's frequency analyses revealed that most of the tree species were rare, as in the case for other tropical forests. In all forest types, 60\%-95\% of tree species were in the lowest frequency class (Figure 5). Furthermore, there were few individuals in the $80 \%-100 \%$ frequency class. In forest types other than DECI, $58 \%-70 \%$ of trees were in the smallest girth category (gbh $50-100 \mathrm{~cm}$ ); in DECI, only $37 \%$ 


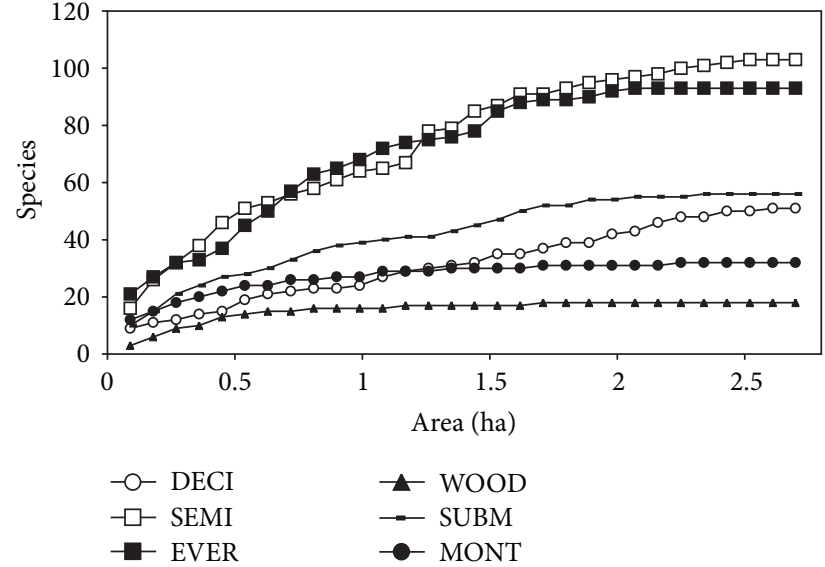

(a)

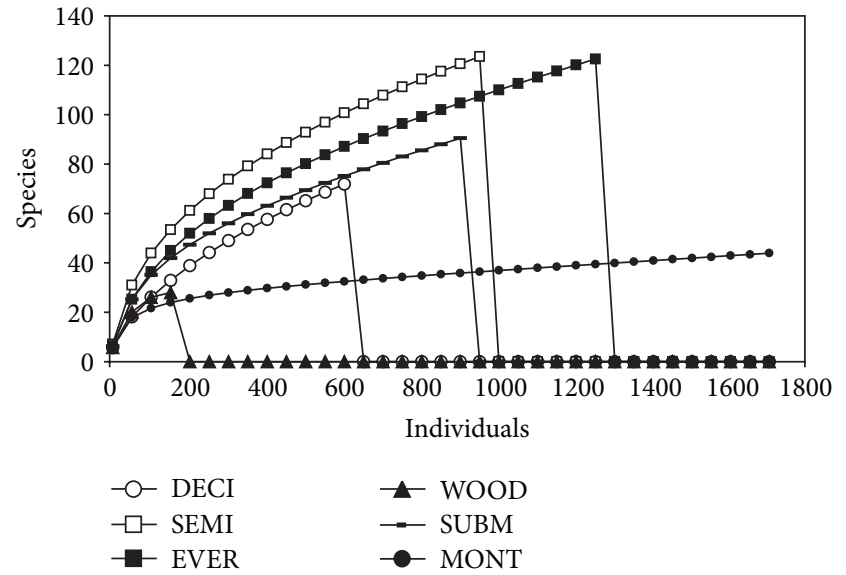

(b)

FIGURE 3: Species accumulation and rarefaction curves of different vegetation types. Curves were created random series of 30 plots of 0.09 ha (i.e., 2.7 ha for each vegetation type). (a) Species-area curves (sample-based rarefaction) and (b) species-individuals curve (individuals-based rarefaction). Looking at the individual-based rarefaction curve, all four vegetation types seem to be quite similar in species richness, except MONT, which is drastically lower although containing the highest number of individuals, WOOD, which contain too few individuals to produce a comparable result. The sample-based rarefaction, on the other hand, identifies SEMI and EVER as the two most species rich communities, differing from the rest. Rarefaction curves for six vegetation types predict the rate of accumulation of species with increasing number of individuals (abundance). See Table 1 for an explanation of vegetation type abbreviations.

TABLE 2: Vegetation parameters calculated for three tree phases in different vegetation types. See Table 1 for explanation of vegetation type abbreviations.

\begin{tabular}{|c|c|c|c|c|c|}
\hline $\begin{array}{l}\text { Vegetation types } \\
\text { (Altitude range) }\end{array}$ & $\begin{array}{l}\text { Rainfall } \\
(\mathrm{mm})\end{array}$ & $\begin{array}{c}\text { Mean temperature } \\
\text { in the coldest } \\
\text { month }\left({ }^{\circ} \mathrm{C}\right)\end{array}$ & $\begin{array}{c}\text { Phases of } \\
\text { trees }\end{array}$ & $\begin{array}{l}\text { Basal area } \\
\left(\mathrm{m}^{2} / \mathrm{ha}\right)\end{array}$ & $\begin{array}{l}\text { Shannon } \\
\text { index }\end{array}$ \\
\hline \multirow{3}{*}{$\begin{array}{l}\text { DECI } \\
(40-400 \mathrm{~m})\end{array}$} & \multirow{3}{*}{$1000-1500$} & \multirow{3}{*}{28} & Mature trees & 23.32 & 2.79 \\
\hline & & & Saplings & 0.20 & 2.48 \\
\hline & & & Seedlings & - & 2.62 \\
\hline \multirow{3}{*}{$\begin{array}{l}\text { SEMI } \\
(400-650 \mathrm{~m})\end{array}$} & \multirow{3}{*}{$2500-3500$} & \multirow{3}{*}{24} & Mature trees & 45.66 & 3.67 \\
\hline & & & Saplings & 0.89 & 3.15 \\
\hline & & & Seedlings & - & 3.11 \\
\hline \multirow{3}{*}{$\begin{array}{l}\text { EVER } \\
(650-1200 \mathrm{~m})\end{array}$} & \multirow{3}{*}{$3500-5000$} & \multirow{3}{*}{22} & Mature trees & 48.00 & 3.34 \\
\hline & & & Saplings & 1.24 & 3.09 \\
\hline & & & Seedlings & - & 3.49 \\
\hline \multirow{3}{*}{$\begin{array}{l}\text { WOOD } \\
(900-1400 \mathrm{~m})\end{array}$} & \multirow{3}{*}{$3500-5000$} & \multirow{3}{*}{25} & Mature trees & 0.69 & 2.21 \\
\hline & & & Saplings & 0.4 & 2.16 \\
\hline & & & Seedlings & - & 1.56 \\
\hline \multirow{3}{*}{$\begin{array}{l}\text { SUBM } \\
(1200-1800 \mathrm{~m})\end{array}$} & \multirow{3}{*}{$5000-6000$} & \multirow{3}{*}{13} & Mature trees & 36.51 & 3.26 \\
\hline & & & Saplings & 0.69 & 3.45 \\
\hline & & & Seedlings & - & 3.51 \\
\hline \multirow{3}{*}{$\begin{array}{l}\text { MONT } \\
(1800-2450 \mathrm{~m})\end{array}$} & \multirow{3}{*}{$5000-6000$} & \multirow{3}{*}{9} & Mature trees & 30.87 & 3.21 \\
\hline & & & Saplings & 1.45 & 3.19 \\
\hline & & & Seedlings & - & 2.71 \\
\hline
\end{tabular}

${ }^{*}$ Mature trees ( $\geq 30 \mathrm{~cm}$ gbh), saplings $(\geq 10<30 \mathrm{~cm}$ gbh), and seedlings $(<10 \mathrm{~cm}$ gbh).

of trees were in the smallest girth class (Figure 6). In WOOD vegetation, which was fire affected and grass dominated, 96\% of trees were in the smallest girth class.

3.2. Regeneration. Frequencies of regenerating species (saplings + seedlings) were maximal in undisturbed forest compared to disturbed one (caused by fuel wood collection and cattle grazing). In DECI, of 71 taxa recorded, only 26 were present in all three growth phases, 24 were present in only one stage, and only 10 species were regenerating well (seedling > sapling > tree). Nevertheless, Lagerstroemia microcarpa, one of the dominant species in DECI, had no seedlings, indicative of poor regeneration potential (Tables 1 and 3; see Supplementary Material Appendix 1 available online at http://dx.doi.org/10.1155/2013/890862). 
TABLE 3: Distribution pattern of mature and regenerating phases of trees occur in different vegetation types. Regenerating species and species share in all phases of trees was lower in disturbed vegetation type such as DECI and WOOD as compared to other vegetation types. Percent similarity in species composition (using Sorenson index of similarity) of mature trees and regenerating individuals (saplings + seedlings) in different vegetation types of the study area and new species recruited (trees devoid of adult stage) are also shown.

\begin{tabular}{|c|c|c|c|c|c|c|}
\hline \multirow[b]{2}{*}{$\begin{array}{l}\text { Vegetation } \\
\text { types }\end{array}$} & \multicolumn{3}{|c|}{ Tree species occur in } & \multirow[b]{2}{*}{$\begin{array}{l}{ }^{*} \text { Regenerating } \\
\text { species }(\%)\end{array}$} & \multirow{2}{*}{$\begin{array}{l}\text { \% Similarity between } \\
\text { mature trees and } \\
\text { regenerating individuals }\end{array}$} & \multirow[b]{2}{*}{$\begin{array}{l}\text { New entry } \\
\text { species (\%) }\end{array}$} \\
\hline & All phases (\%) & $\begin{array}{c}\text { Mature phase } \\
\text { only }(\%)\end{array}$ & $\begin{array}{c}\text { Regenerating } \\
\text { phase only }(\%)\end{array}$ & & & \\
\hline DECI & $26(37)$ & $21(30)$ & $12(17)$ & $50(70)$ & 69 & $12(17)$ \\
\hline SEMI & $53(41)$ & $11(9)$ & $27(21)$ & $116(91)$ & 82 & $24(18)$ \\
\hline EVER & $49(40)$ & $11(9)$ & $24(20)$ & $111(91)$ & 81 & $23(18)$ \\
\hline WOOD & $8(29)$ & $8(29)$ & $11(39)$ & $20(71)$ & 49 & $10(35)$ \\
\hline SUBM & $40(43)$ & $4(4)$ & $18(20)$ & $87(95)$ & 88 & $20(21)$ \\
\hline MONT & $20(47)$ & $6(14)$ & $11(26)$ & $37(86)$ & 76 & $10(23)$ \\
\hline
\end{tabular}

${ }^{*}$ A number of species occur in saplings and/or seedlings, and these species may or may not have mature tree stage; $\%$ of species has been given in brackets.

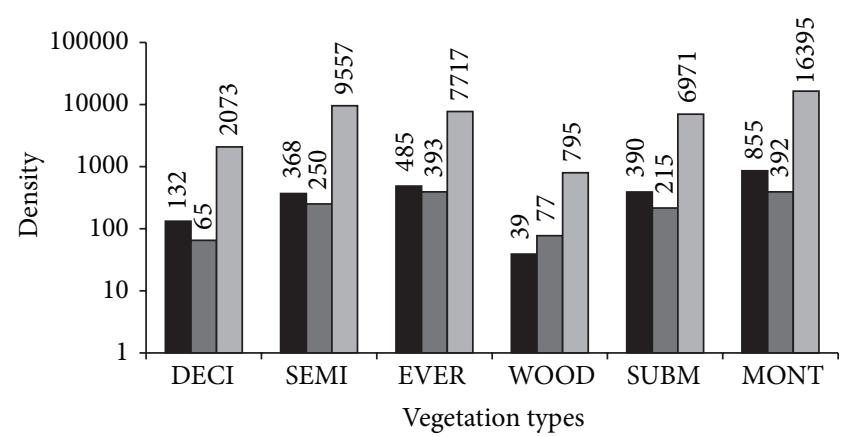

Mature trees
Saplings
Seedlings

FIGURE 4: Densities (no ha ${ }^{-1}$ in $\log _{10}$ scale) of mature trees $(\geq 30 \mathrm{~cm}$ gbh (girth at breast height)), saplings ( $\geq 10<30 \mathrm{~cm}$ gbh), and seedlings $(<10 \mathrm{~cm} \mathrm{gbh})$ in six vegetation types occurring in the Western Ghats. LSD post hoc test clarified that density of disturbed forest like DECI and WOOD was significantly different with undisturbed vegetation type except MONT.

In vegetation types influenced by disturbance and fire, like WOOD, $29 \%$ of species were common in all growth phases and seedling richness was very low in these types of vegetation (Supplementary Material Appendix 2).

In vegetation types at mid elevations, namely, EVER and SEMI, $49 \%-53 \%$ of species were present in all growth phases; $25-30 \%$ of species occurred in only one phase (Supplementary Material Appendices 3 and 4). In forests at higher elevations, namely,SUBM and MONT, 43\% and $47 \%$ of species, respectively, were present in all growth phases. In SUBM, 25 species had poor regeneration potential (Supplementary Material Appendix 5). In MONT, 20 species were present in all growth phases, and 12 had no regeneration potential (Table 3, Supplementary Material Appendix 6).

3.3. Change in Species Composition among Tree Phases. Overall species richness of mature trees was higher than richness of saplings and seedlings in all vegetation types. Among the dominant species, a few trees had exceptionally large numbers of seedling and saplings. Individual trees did not contribute equally to the seedling population or to later recruitment in the sapling stage. Density of regenerating individuals (saplings + seedlings) was highest in EVER and lowest in WOOD. There was significant difference in the density of regenerating individuals (seedling + saplings) among different vegetation types $\left(F_{5,611}=13.2, P<0.001\right)$. Also, there was significant difference in the density of mature and regenerating phase among all vegetation types except WOOD (DECI: $F_{1,130}=11.7, P<0.001$; SEMI: $F_{1,269}=3.7$, $P<0.05$; EVER: $F_{1,255}=7.3, P<0.008$; WOOD: $F_{1,41}=3.4$, $P<0.059$; SUBM: $F_{1,201}=10.1, P<0.002$; MONT: $F_{1,88}=$ 5.1, $P<0.026)$.

The overall changes in species composition from mature stage to regenerating stage (sapling + seedling phases) of different vegetation types $21 \%$ that is, $79 \%$ similarity (using Sorenson index of similarity) between mature and regenerating phase. In disturbed WOOD and DECI, the similarity in species composition between mature trees and regenerating individuals was 49\% and 69\%, respectively. In little-disturbed vegetation types, species similarity between mature trees and regenerating phases was relatively high. In all the forest types, new entry species (tree species with no adult stages) were present. Percent of new entry species was highest in fire affected WOOD vegetation (Table 3 ).

\section{Discussion}

4.1. Species Diversity. The use of species-individuals curves in addition to species-area curves provides a clear insight into species diversity. More sampling area is required for species rich vegetation type compared to species poor one, and in general, the minimum area varies with number of species from one vegetation type to another [51]. In our data, speciesrich communities like SEMI and EVER seem to have less dominance than species-poor communities. However, lower rarefaction curve in MONT suggests that abundance effect may not be the sole reason for high richness. The accumulation of new species with increasing sampling effort can be visualized with a species accumulation curve. Increasing 


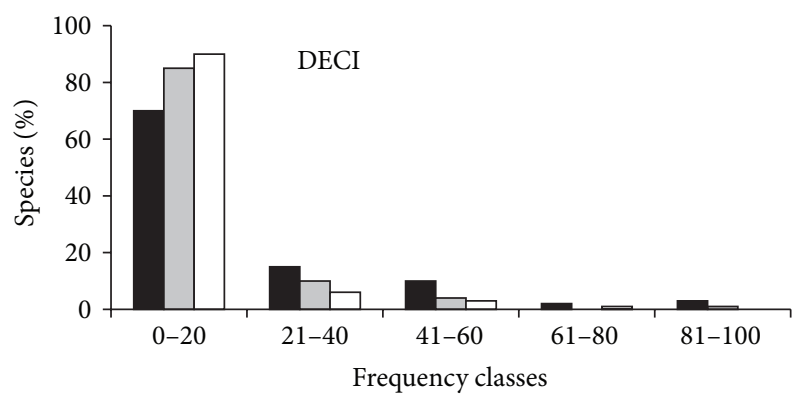

(a)

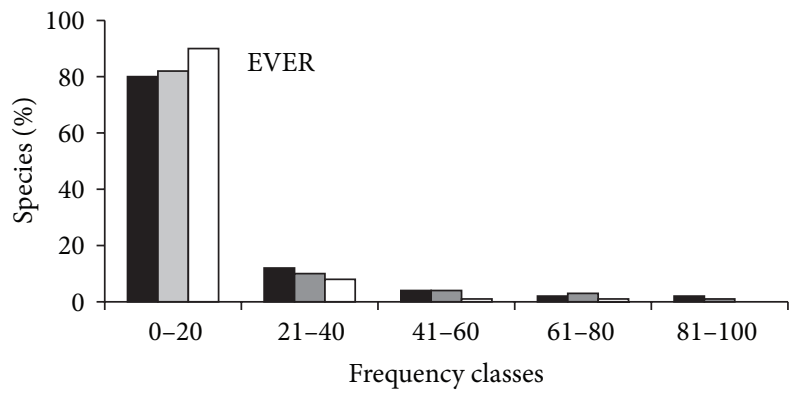

(c)

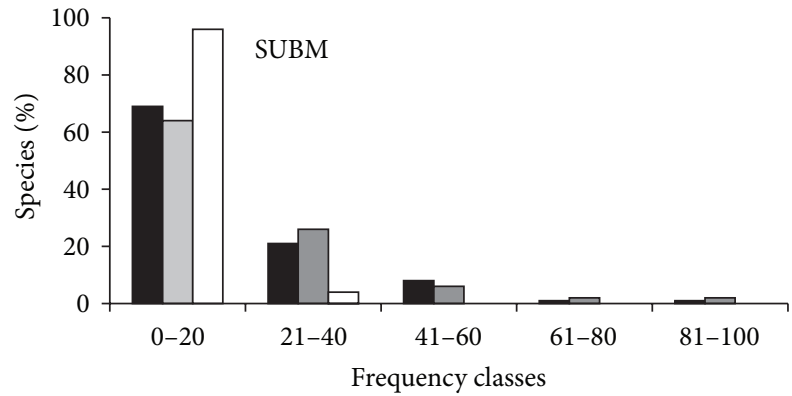

Mature trees

Saplings

Seedlings

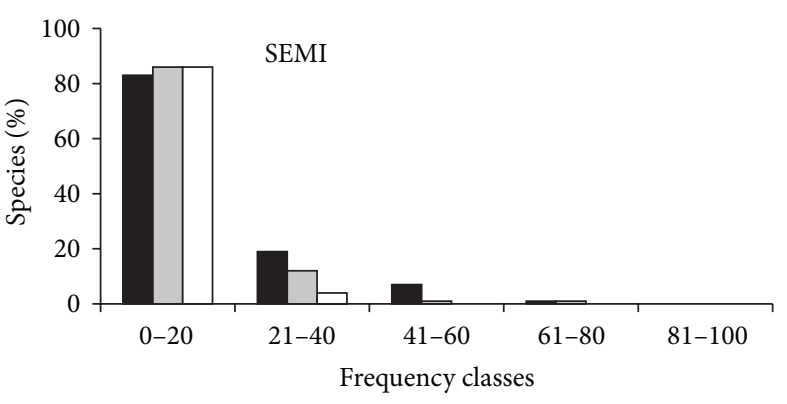

(b)

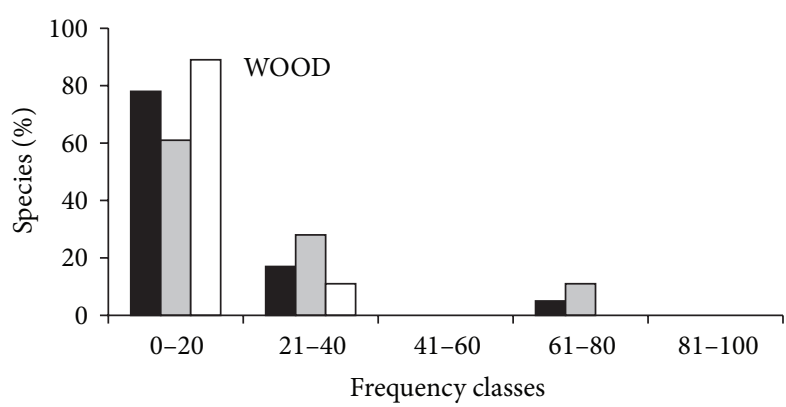

(d)

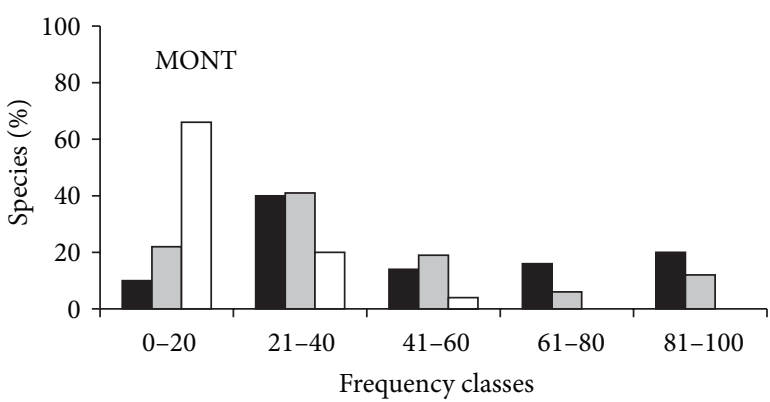

Mature trees

Saplings

$\square$ Seedlings

(e)

(f)

FIGURE 5: Percent frequencies of trees ( $\geq 30 \mathrm{~cm}$ gbh) in different vegetation types. Most of the species were in the lowest frequency class in all vegetation types other than MONT, indicating that a few species were widely distributed; most were restricted in distribution. This is a typical species-abundance distribution (normal distribution) and the tree species in all the vegetation type were heterogeneous distribution in Raunkiaer's sense.

the area sampled increases observed species richness both because more individuals get included in the sample and because large areas are environmentally more heterogeneous than small areas [52]. The correlation between species richness and abundance suggests that process affecting change in either richness or abundance also affects species diversity.

Species richness of DECI was reduced, likely due to low rainfall and anthropogenic disturbances such as firewood collection and cattle grazing. In fire affected WOOD, grasses were the dominant life forms; these were intermingled with a few fire tolerant, light demanding trees. High species richness of trees in SEMI, EVER, and SUBM was probably related to high rainfall and optimal climatic conditions (Table 2). Low temperature and high wind velocity in the MONT may negatively impact tree growth and reduce species richness there. DECI stands were dominated by members of the family Fabaceae, while Euphorbiaceae and Rubiaceae dominated in EVER at mid elevations. High elevation SUBM and MONT were dominated by members of the Lauraceae and Myrtaceae, which have volatile oils in their tissues that resist freezing damage in plant cells [53].

Compared to DECI, tree species diversity was very high in other forest types at higher elevations other than in the fire-affected WOOD. High species diversity of SEMI is due its transitional nature; that is, this vegetation type is ecotone area suitable for both deciduous and evergreen tree species; so there is an increase in the number of species. Species diversity indices for saplings were lower than those for mature trees 


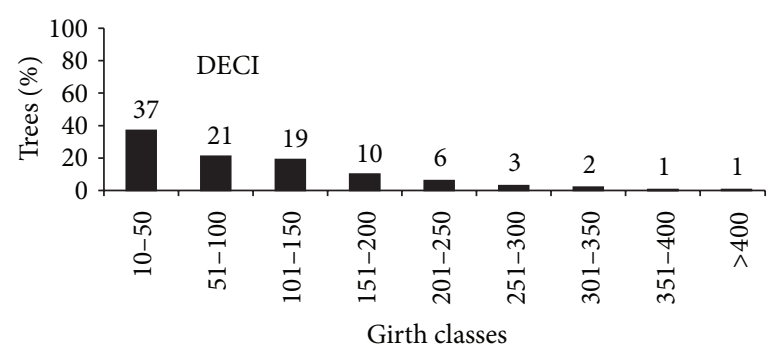

(a)

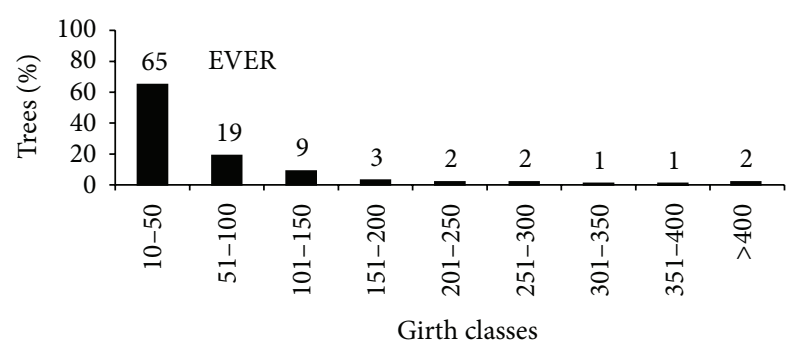

(c)

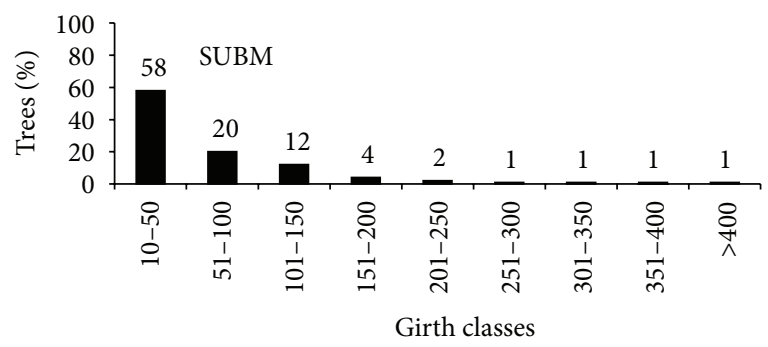

(e)

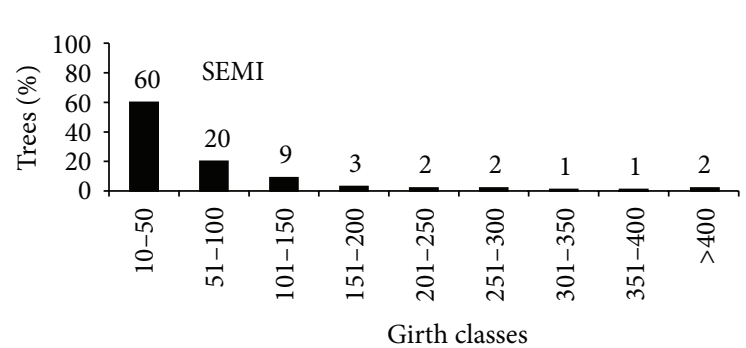

(b)

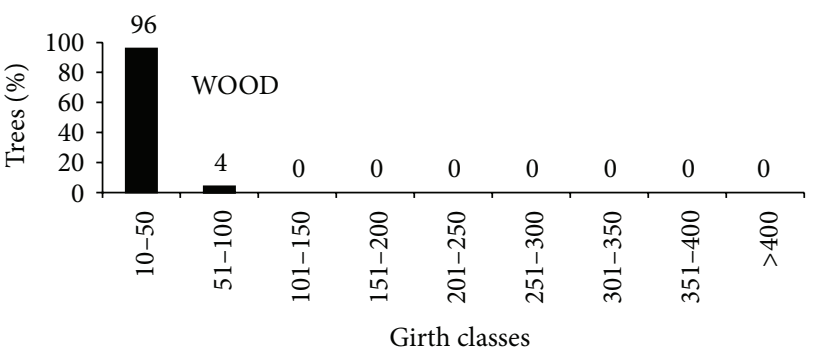

(d)

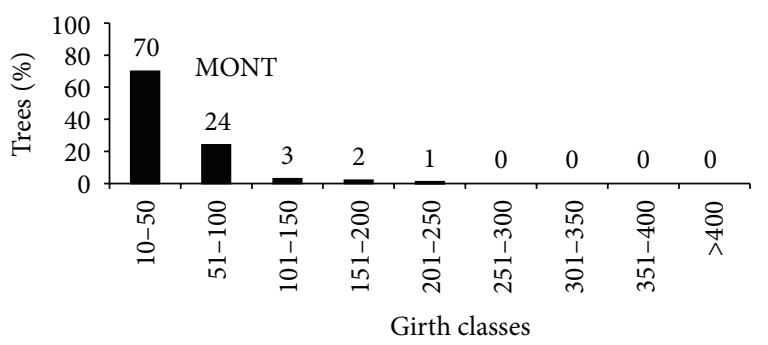

(f)

FIGURE 6: Girth frequency distributions of trees in different vegetation types of the study area. Girth-size was highest in SEMI and EVER. A high percentage of lower girth class trees in DECI results from reduced fuel wood extraction by people of nearby areas. The reverse J-shaped gbh distribution of trees indicates evolving or expanding population.

and seedlings in DECI is due to overharvesting of saplings for firewood. The lowest species diversity value in WOOD indicates low species richness and dominance of one or two species in the tree community. In the present study, Shannon index values for tree species are similar to values for other tropical forests of the world (Table 4). However, detailed comparisons with other studies are inadvisable because of large differences in sample size, standard girth parameters, and environmental conditions.

Density and frequency distributions of trees contribute to the structure of tropical forests. Tree density in DECI was much lower than that of other forest types, perhaps due to low rainfall and anthropogenic disturbances. Density was least in the fire-affected WOOD. Sapling densities were elevated in SEMI and EVER. Late secondary successional species were well represented in the sapling population of EVER, which may be indicative of recent natural disturbances in this forest type that promoted regeneration of late secondary species. MONT had high sapling density, due to the stunted nature of trees caused by very low temperature and high wind velocity prevalent there [54].
Densities of trees in the study area were similar to estimates from tropical forests within India and other tropical regions (Table 4). In tropical forests outside India there is much variation in the densities of trees $>30 \mathrm{~cm}$ gbh (981930 trees $\mathrm{ha}^{-1}$ ), especially in Amazonian forests. In the Neotropics, maximum species richness of tree individuals $>10 \mathrm{~cm}$ gbh reaches $300 \mathrm{ha}^{-1}$ [55]. In South-East Asia, the highest richness is $225 \mathrm{ha}^{-1}$ [56].

In the present study, most of the species were in frequency class $0 \%-20 \%$ and fewest were in frequency class $80 \%-100 \%$. The frequency distribution of tree species suggested that most of them had low frequency as would be expected in typical species-abundance distribution. A plant species should be considered homogeneously distributed when the numbers of individuals are the same in all parts of a community [50]. Hence, tree species in all the vegetation types of the study area were heterogeneously distributed. Girth class frequency distributions of most species in vegetation types we studied fit "reverse J"-shaped patterns, with most trees in smaller girth classes and few old trees. Vegetation types other than WOOD fit negative exponential patterns indicative of 


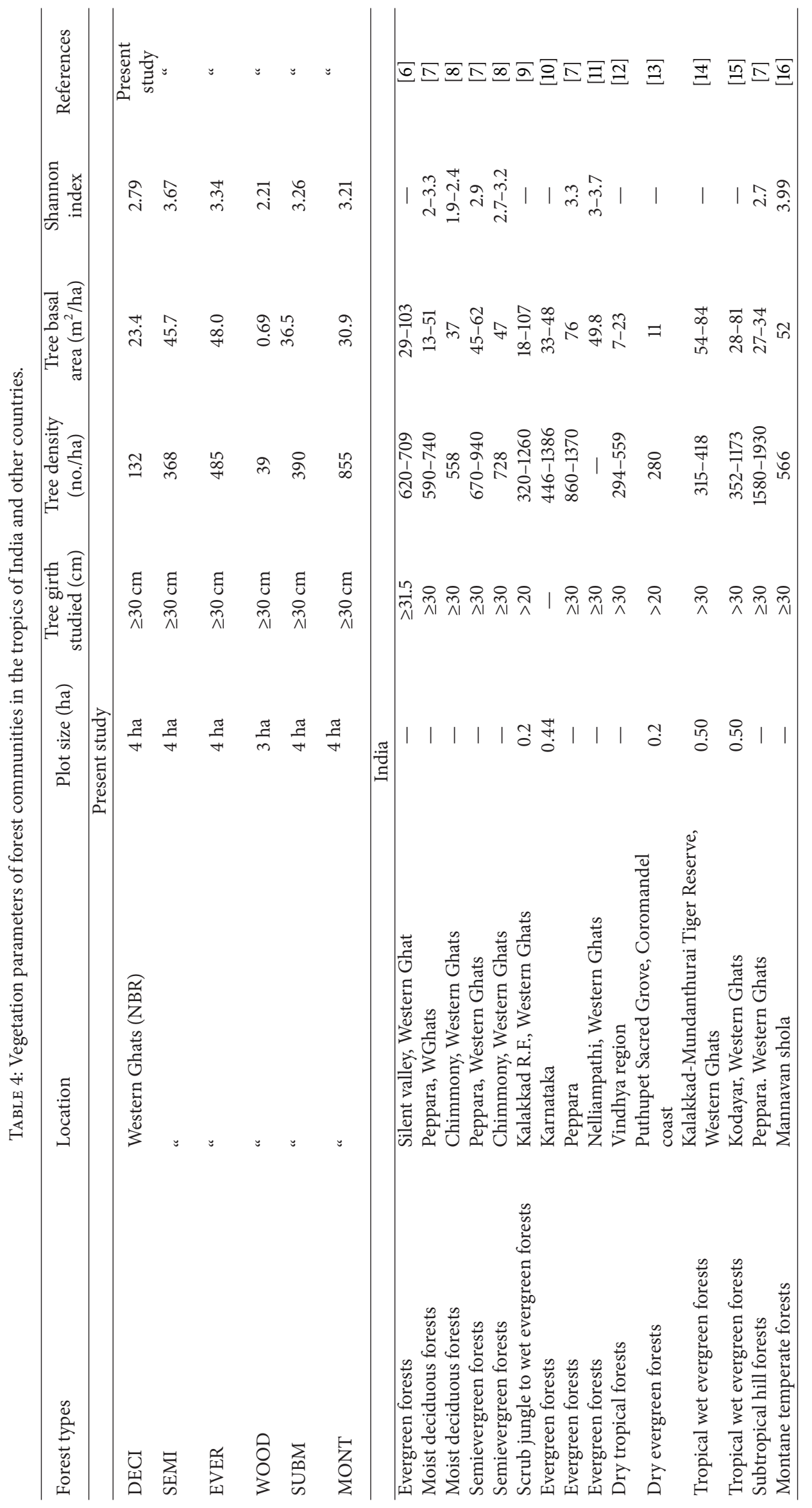




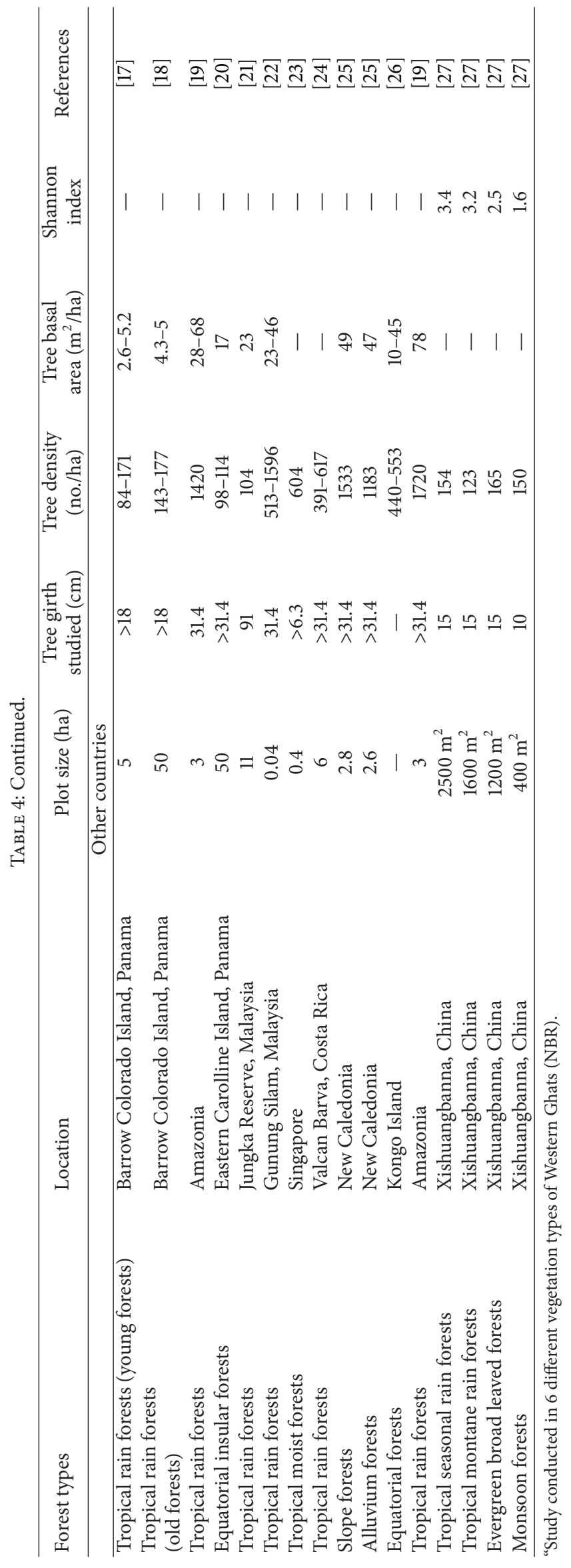


relatively undisturbed or less disturbed conditions in the stands. The high annual precipitation rate and optimum temperature of EVER may have contributed to high tree growth rate and higher tree basal area.

4.2. Regeneration. All other vegetation types had better regeneration than DECI. In WOOD, the transition rate of stems from small girth classes to larger girth classes was low. Poor tree regeneration in DECI and WOOD can probably be attributed to fuel wood collection, frequent fires and grazing by cattle. In all forest types, $29 \%-47 \%$ of tree species were present in all three growth phases; other species were present in either one or two growth phases. Dominant species occurred in all girth classes of vegetation types other than WOOD, in which most trees were in the smaller girth classes. There were more large trees in vegetation types like SEMI and EVER, and in these, sapling and seedling densities were adequate for restocking the complement of canopy trees.

Change in species composition across mature and regenerating tree phases was more frequent in disturbed forest types like DECI and WOOD. In some cases, the dominant species in adult and seedling stages were quite different in these two disturbed forest types. Our results are not congruent with observations made in northeastern India [39] where tree seedling survival rate increases with increasing forest disturbance. We found species without regenerating phases; these are unlikely to persist. Others that occurred only in seedling and sapling stages were new entrants to the forest species complement. These are examples of discontinuous population structures. Such structures occur in a number of other tropical countries [57-59]. The dominant species in a forest stand is generally present in all size classes [38]. The size class structures of trees indicate the probability of species persistence into the future; this information is very valuable in the design of management strategies aiming to improve stand structure and species diversity. Changes in species composition and recruitment of new species in different vegetation types are indicative of future species composition in changing environments.

\section{Conclusions}

The species diversity of trees varied across vegetation types in the Western Ghats landscape. Rarefaction curves show that species diversity is highest in SEMI and EVER and lowest in WOOD while species abundance is highest in MONT. Vegetation types of study area are in heterogeneous in distribution. There were large differences in species composition of adult trees and regenerating individuals in the disturbed vegetation types as compared to undisturbed stands. The present study reveals that the anthropogenic disturbance causes disruption of forest structure and change in species composition which ultimately leads to reduction of tree species richness and abundance which are the major attributes of forests. New recruits were found in all vegetation types, indicating that they were not headed to extinction; however, disturbed stands may move to new species compositions in the future.

\section{Acknowledgments}

The authors are thankful to the Ministry of Environment and Forests for financial support and the Vice Chancellor of University of Delhi, and the Director of Kerala Forest Research Institute for facilities provided. The first author would like to thank Professor C. R. Babu for facilities and encouragement. The authors are very much obliged to all members of the Cholanaikkan tribe, who helped during the field survey. The Kerala Forest Department provided all logistical support for the floristic and ecological survey of the forest area. (trees ha ${ }^{-1}$ ) in three different growth phases of six vegetation

\section{References}

[1] M. A. Huston, Biological Diversity: The Coexistence of Species in Changing Landscapes, Cambridge University Press, Cambridge, UK, 1994.

[2] T. C. Whitmore, An Introduction to Tropical Rain Forests, Oxford University Press, New York, NY, USA, 2nd edition, 1998.

[3] M. L. Khan, S. Menon, and K. S. Bawa, "Effectiveness of the protected area network in biodiversity conservation: a casestudy of Meghalaya state," Biodiversity and Conservation, vol. 6, no. 6, pp. 853-868, 1997.

[4] C. M. Pringle, "Nutrient spatial heterogeneity: effects on community structure, physiognomy, and diversity of stream algae," Ecology, vol. 71, no. 3, pp. 905-920, 1990.

[5] M. Parviainen, M. Marmion, M. Luoto, W. Thuiller, and R. K. Heikkinen, "Using summed individual species models and state-of-the-art modelling techniques to identify threatened plant species hotspots," Biological Conservation, vol. 142, no. 11, pp. 2501-2509, 2009.

[6] J. S. Singh, S. P. Singh, A. K. Saxena, and Y. S. Ravat, "The forest vegetation of Silent Valley," in Tropical. Rain Forests: The Leeds Symposium, pp. 25-52, 1984.

[7] A. O. Varghese, "Assessment of biodiversity of Peppara Wildlife Sanctuary, Trivandrum District, Kerala," Journal of Economic and Taxonomic Botany, vol. 23, pp. 117-127, 1998.

[8] M. A. Suraj, Phytosociological and vagetation mapping at chimmony wildlife Sanctuary (Kerala) using remote sensing technique [Ph.D. thesis], FRI University, Dehradun, India, 1997.

[9] N. Parthasarathy, Studies on the vacular flora, structure and nutrient cycling in Kalakad Reserve Forest, Western Ghats, Tamil Nadu [Ph.D. thesis], University of Madras, Tamil Nadu, India, 1986.

[10] S. N. Rai and J. Proctor, "Ecological studies on four rain forests in Karnataka, India: environment, forest structure and vegetation," Journal of Vegetation Science, vol. 1, pp. 609-614, 1986.

[11] U. M. Chadrashekara, A. R. R. Menon, K. K. N. Nair, N. Sasidharan, and K. Swarupanandan, "Evaluating plant diversity in different forest types of Kerala by laying out permanent sample plots," KFRI Research Report 156, Kerala Forest Research Institute, Peechi, India, 1998.

[12] C. S. Jha and J. S. Singh, "Composition and dynamics of dry tropical Forest in relation to soil texture," Journal of Vegetation Science, vol. 1, no. 5, pp. 609-614, 1990.

[13] N. Visalakshi, "Vegetation analysis of two tropical dry evergreen forests in southern India," Tropical Ecology, vol. 36, no. 1, pp. 117127, 1995. 
[14] T. Ganesh, R. Ganesan, M. Soubadra Devy, P. Davidar, and K. S. Bawa, "Assessment of plant biodiversity at a mid-elevation evergreen forest of Kalakad-Mundanthurai Tiger Reserve, Western Ghats, India," Current Science, vol. 71, no. 5, pp. 379-392, 1996.

[15] S. M. Sundarapandian and P. S. Swamy, "Forest ecosystem structure and composition along an altitudinal gradient in the Western Ghats, South India," Journal of Tropical Forest Science, vol. 12, no. 1, pp. 104-123, 2000.

[16] K. Swarupanandan, N. Sasidharan, K. C. Chacko, and S. ChanduBasha, "Floristic and ecological studies on the Sholas of Idukki District," in Shola Forests of Kerala: Environment and Biodiverstiy, K. K. N. Nair, S. K. Khanduri, and K. Balasubramaniayan, Eds., pp. 259-286, Kerala Forest Deparment, Thiruvanathapuram, Kerala Forest Research Institute, Peechi, India, 2001.

[17] R. W. Thorington, S. Tannenbaum, A. Tarak, and R. Rudran, "Distribution of trees in Baro Colorado Islands: a hectare sample," in The Ecology of a Tropical Forest-Seasonal Rhythms and Long-term Changes, E. G. Leigh Jr., A. S. Rand, and D. M. Windsor, Eds., Smithsonian Institute Press, Washington, DC, USA, 1982.

[18] S. P. Hubbell and R. B. Foster, "Diversity of canopy species in a neotropical forest and implications for conservation," in Tropical Rain Forest: Ecology and Management, S. L. Sutton, T. C. Whitmore, and A. C. Chadwick, Eds., Blackwell, Oxford, UK, 1983.

[19] D. G. Campbell, D. C. Daly, G. T. Prance, and U. N. Maciel, "Quantitative ecological inventory of terra firme and várzea tropical forest on the Rio Xingu, Brazilian Amazon," Brittonia, vol. 38, no. 4, pp. 369-393, 1986.

[20] S. Itow, "Species diversity of equatorial insular forests on Ponape and Kosrae, Micronesia," Ecological Research, vol. 1, no. 2, pp. 223-227, 1986.

[21] C. C. Ho, D. M. Newbery, and M. E. D. Poore, "Forest composition and inferred dynamics in Jengka Forest Reserve, Malaysia," Journal of Tropical Ecology, vol. 3, no. 1, pp. 25-56, 1987.

[22] J. Proctor, Y. F. Lee, A. M. Langley, W. R. C. Munro, and T. Nelson, "Ecological studies on Gunung Silam, a small ultrabasic mountain Sabah, Malaysia," Journal of Ecology, vol. 74, pp. 455463, 1988 .

[23] F. R. Swan Jr., "Tree distribution patterns in the Bukittimah nature reserve, Singapore," Gardens Bulletin, vol. 41, pp. 59-81, 1988.

[24] A. Heaney and J. Proctor, "Preliminary studies on forest structure and floristics on Volcan Barva, Costa Rica," Journal of Tropical Ecology, vol. 6, no. 3, pp. 307-320, 1990.

[25] T. Jaffré and J. M. Veillon, "Etude floristique et structurale de deux forêts denses humides sur roches ultrabasiques en Nouvelle- Calédonie," Bulletin du Museum National d'Histoire Naturelle, vol. 12, pp. 243-273, 1990.

[26] M. Mosango, "Contribution "A l'étude botanic biogéo 1" ecosystem Forêt en région equatorial (Ile Kongolo,Zaire)," Belgium Journal of Botany, vol. 124, pp. 167-194, 1991.

[27] M. Cao and J. Zhang, "Tree species diversity of tropical forest vegetation in Xishuangbanna, SW China," Biodiversity and Conservation, vol. 6, no. 7, pp. 995-1006, 1997.

[28] C. S. Jha, L. Goparaju, A. Tripathi, B. Gharai, A. S. Raghubanshi, and J. S. Singh, "Forest fragmentation and its impact on species diversity: an analysis using remote sensing and GIS," Biodiversity and Conservation, vol. 14, no. 7, pp. 1681-1698, 2005.
[29] P. S. Roy, C. B. S. Dutt, and P. K. Joshi, "Tropical forest resource assessment and monitoring," Tropical Ecology, vol. 43, no. 1, pp. 21-37, 2002.

[30] R. Sagar, A. S. Raghubanshi, and J. S. Singh, "Asymptotic models of species-area curve for measuring diversity of dry tropical forest tree species," Current Science, vol. 84, no. 12, pp. 15551560, 2003.

[31] R. Sukumar, H. S. Dattaraja, H. S. Suresh et al., "Long-term monitoring of vegetation in a tropical deciduous forest in Mudumalai, southern India," Current Science, vol. 62, pp. 608616,1992

[32] U. M. Chandrashekara and P. S. Ramakrishnan, "Vegetation and gap dynamics of a tropical wet evergreen forest in the Western Ghats of Kerala, India," Journal of Tropical Ecology, vol. 10, no. 3, pp. 337-354, 1994.

[33] T. Ganesh, R. Ganesan, M. Soubadra Devy, P. Davidar, and K. S. Bawa, "Assessment of plant biodiversity at a mid-elevation evergreen forest of Kalakad-Mundanthurai Tiger Reserve, Western Ghats, India," Current Science, vol. 71, no. 5, pp. 379-392, 1996.

[34] J. P. Pascal and R. Pelissier, "Structure and floristic composition of a tropical evergreen forest in south-west India," Journal of Tropical Ecology, vol. 12, no. 2, pp. 191-210, 1996.

[35] N. Ayyappan and N. Parthasarathy, "Biodiversity inventory of trees in a large-scale permanent plot of tropical evergreen forest at Varagalaiar, Anamalais, Western Ghats, India," Biodiversity and Conservation, vol. 8, no. 11, pp. 1533-1554, 1999.

[36] A. Kumar, B. G. Marcot, and A. Saxena, "Tree species diversity and distribution patterns in tropical forests of Garo Hills," Current Science, vol. 91, no. 10, pp. 1370-1381, 2006.

[37] N. Parthasarathy, "Tree diversity and distribution in undisturbed and human-impacted sites of tropical wet evergreen forest in southern Western Ghats, India," Biodiversity and Conservation, vol. 8, no. 10, pp. 1365-1381, 1999.

[38] M. L. Khan, J. P. N. Rai, and R. S. Tripathi, "Population structure of some tree species in disturbed and protected subtropical forests of north-east India," Acta Oecologica, vol. 8, no. 3, pp. 247-255, 1987.

[39] R. S. Tripathi and M. L. Khan, "Regeneration pattern and population structure of trees in subtropical forest of North East India," in Tropical Ecosystem-Ecology and Management, K. P. Singh and J. S. Singh, Eds., pp. 431-441, Wiley Eastern Limited, New Delhi, India, 1992.

[40] A. E. Scholl and A. H. Taylor, "Regeneration patterns in oldgrowth red fir-western white pine forests in the northern Sierra Nevada, Lake Tahoe, USA," Forest Ecology and Management, vol. 235, no. 1-3, pp. 143-154, 2006.

[41] D. A. Clark, "Regeneration of canopy trees in tropical wet forests," Trends in Ecology and Evolution, vol. 1, no. 6, pp. 150154, 1986.

[42] P. C. J. Barker and J. B. Kirkpatrick, "Phyllocladus aspleniifolius: variability in the population structure, the regeneration niche and dispersion patterns in Tasmanian forests," Australian Journal of Botany, vol. 42, no. 2, pp. 163-190, 1994.

[43] C. K. Augspurger, "Seedling survival of tropical tree species: interactions of dispersal distance, light-gaps, and pathogens," Ecology, vol. 65, no. 6, pp. 1705-1712, 1984.

[44] O. L. Phillips, "Long-term environmental change in tropical forests: increasing tree turnover," Environmental Conservation, vol. 23, no. 3, pp. 235-248, 1996.

[45] Ministry of Environment and Forests, "Plant discoveries 2011: new genera, species and new records," Botanical Survey of India, Ministry of Environment and Forests, New Delhi, India, 2012. 
[46] "Weblink 2007," http://www.biodiversityhotspots.org/xp/hotspots/hotspots_by_region.

[47] D. Mueller-Dombois and H. Ellenberg, Aims and Methods of Plant Ecology, John Wiley \& Sons, New York, NY, USA, 1974.

[48] K. K. N. Nair and R. Jayakumar, "Phytogeography, endemism and affinities of the flora of New Amarambalam Reserve Forests in the Western Ghats of India," Indian Journal of Forestry, vol. 31, pp. 85-94, 2008.

[49] A. E. Magurran, Ecological Diversity and Its Measurement, Croom Helm. Ltd., London, UK, 1988.

[50] C. Raunkiaer, The Life Forms of Plants and Statistical Plant Geography, Clarendon Press, Oxford, UK, 1934.

[51] B. Rice and M. Westoby, "Plant species richness at the 0.1 hectare scale in Australian vegetation compared to other continents," Vegetatio, vol. 52, no. 3, pp. 129-140, 1983.

[52] S. M. Scheiner, "Six types of species-area curves," Global Ecology and Biogeography, vol. 12, no. 6, pp. 441-447, 2003.

[53] H. G. Jones, Plants and Microclimate, Cambridge University Press, Cambridge, UK, 1983.

[54] N. C. Nair, The Southern Western Ghats: A Biodiversity Conservation Plan, Indian National Trust for Arts and Cultural Heritage, New Delhi, India, 1991.

[55] A. H. Gentry, "Changes in plant community diversity and floristic composition on environmental and geographical gradient," Annals of the Missouri Botanical Garden, vol. 75, no. 1, pp. 1-34, 1988.

[56] T. C. Whitmore, Tropical Rain Forests of the Far East, Clarendon Press, Oxford, UK, 1984.

[57] N. V. L. Brokaw, "Gap-phase regeneration of three pioneer tree species in a tropical forest," Journal of Ecology, vol. 75, no. 1, pp. 9-19, 1987.

[58] S. Itow and D. Mueller-Dombois, "Population structure, standlevel dieback and recovery of Scalesia pedunculata forest in the Galápagos Islands," Ecological Research, vol. 3, no. 3, pp. 333339, 1988.

[59] T. C. Whitmore, "A review of some aspects of tropical rainforest seedling ecology with suggestions for further enquiry," in Ecology of Tropical Forest Tree Seedlings, M. D. Swaine, Ed., pp. 3-39, UNESCO/Parthenon, Paris, France, 1996. 

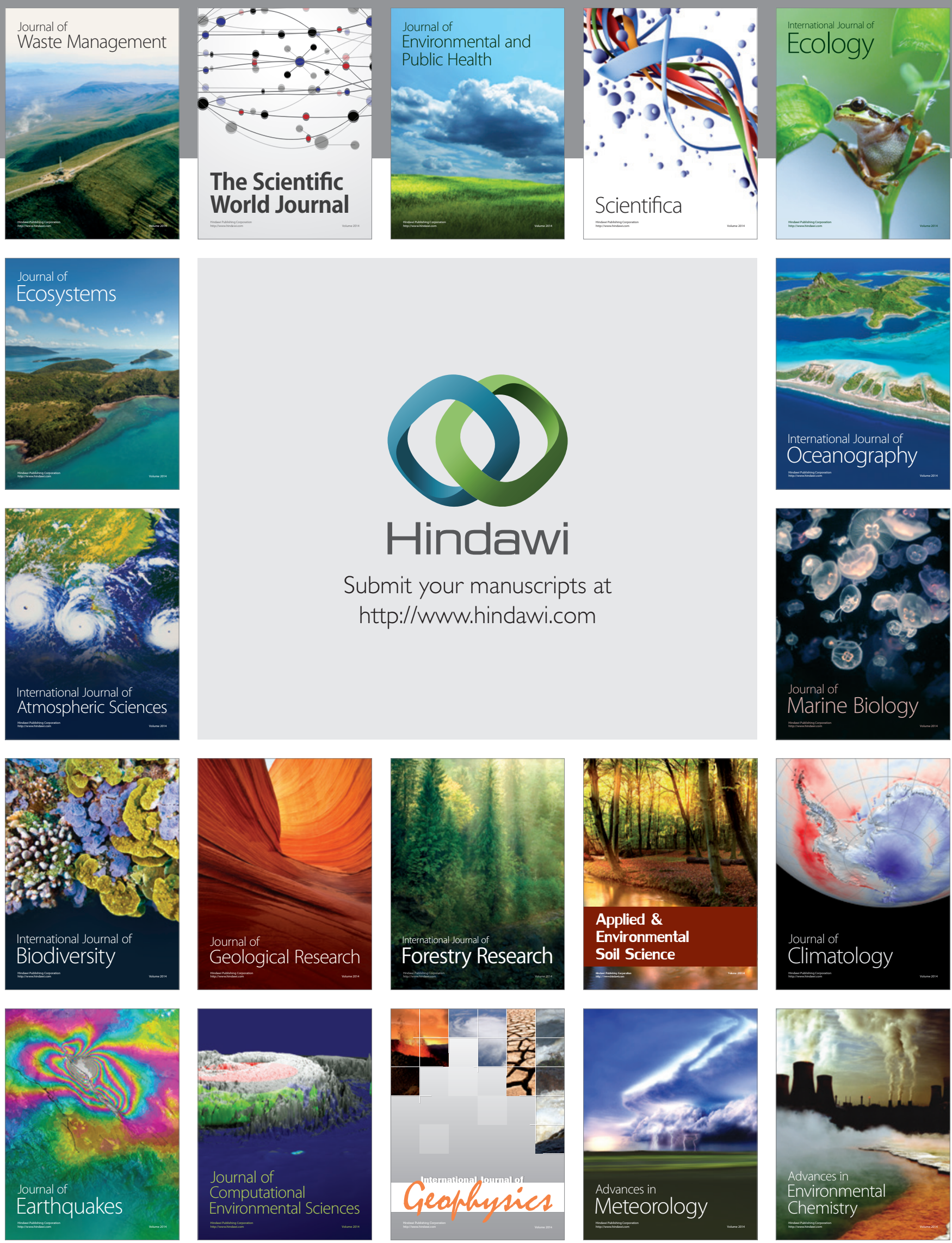